\title{
HEURISTIC REASONING IN INTERPRETING BOX PLOTS: THE INFLUENCE OF ORIENTATION
}

\author{
Stephanie LEM $^{1}$, Claudia VANDEBEEK ${ }^{1}$, Patrick ONGHENA², Lieven VERSCHAFFEL ${ }^{1}$, \\ Wim VAN DOOREN ${ }^{1}$ \\ ${ }^{1}$ Centre for Instructional Psychology and Technology \\ Dekenstraat 2, PO Box 3773, 3000 Leuven, Belgium \\ E-mail: Stephanie.Lem@ppw.kuleuven.be \\ ${ }^{2}$ Methodology of Educational Sciences Research Group, KU Leuven, Belgium
}

\begin{abstract}
We studied how graph design principles can predict specific reasoning mechanisms that occur when misinterpreting box plots, and, more specifically, the misinterpretation of the area as a representation of frequency or proportion of observations, instead of density. In previous studies this misinterpretation has been shown to be heuristic in nature and is elicited by the fact that box plots do not use space in a natural way. Graph design principles provide a theoretical framework for assuming that the orientation of a box plot could influence its interpretation. By analyzing reaction times and accuracy rates for different item types, we explored whether there indeed is an influence of the orientation of a box plot on the way it is interpreted. Results indicate that the misinterpretation manifests itself in both orientations to the same extent, suggesting that the orientation of a box plot does not influence the reasoning mechanisms it provokes.
\end{abstract}

Key words: dual-process theory, graph design, misinterpretation, heuristic, box plots

Lem, Onghena, Verschaffel, and Van Dooren (2013b) recently showed that box plots are misinterpreted frequently and that the incorrect interpretation of the area of the box plot can be assigned to incorrect heuristic reasoning. A limitation of this study is, however, that it only used horizontally positioned box plots, while it is also common practice to make use of vertically positioned box plots, particularly when multiple groups are being compared (e.g., McGill, Tukey, Larsen, 1978; Williamson, Parker, Kendrick,

Acknowledgements: Stephanie Lem holds a $\mathrm{PhD}$ fellowship of the Research Foundation - Flanders (FWO). This research was partially supported by grant GOA/12/010 'Number sense: Analysis and Improvement' of the KU Leuven.
1989). Based on graph design principles (Tversky, 1997), some arguments can be given that make it likely that less interpretation difficulties will occur when the box plot is represented vertically. In the present study, we compared the way horizontally and vertically positioned box plots are interpreted, using a dual processing perspective.

\section{The Heuristic Misinterpretation of Box Plots}

The misinterpretation, which is the focus in this study, was documented first by Bakker, Biehler, and Konold (2005). They found that the area of the box plot is often perceived by students as displaying the frequency or proportion of observations in that

DOI: $10.21909 / \mathrm{sp} .2014 .02 .655$ 
interval, instead of the density. Bakker et al. ascribed this misinterpretation to the fact that students link the use of box plots to the use of graphical representations previously learned in school (e.g., histograms and bar graphs, see also Lem, Onghena, Verschaffel, Van Dooren, 2012). In box plots the area of the box indicates how dense the observations are in that interval: The smaller an area, the higher the density of observations in that interval. This makes box plots very different from other graphical representations, such as bar graphs and histograms, in which a larger area of the bar reflects a higher frequency of observations.

Using the dual processes approach, Lem et al. (2013b) found indications for the heuristic nature of the misinterpretation of the area in box plots. Despite some criticism (Keren, Schul, 2009), the dual processes approach has been frequently and successfully used in the past decades to study whether certain reasoning errors can be explained by the incorrect heuristic or intuitive processing of certain task characteristics. In Lem et al.'s (2013b) investigation, reaction times and accuracy rates of two item types were compared to study the occurrence of heuristic reasoning: congruent and incongruent items. In congruent items, the correct response is in line with the expected heuristic reasoning. Thus, they can be solved very fast by heuristic reasoning. For incongruent items, on the other hand, the heuristic reasoning leads to an incorrect response. Therefore, they need analytic reasoning to find the correct response, which takes longer. Participants were asked to solve congruent and incongruent items concerning box plots. Reaction times and accuracy rates were logged on both item types. Participants solved congruent items correctly significantly more often than incongruent items, and longer reaction times were registered on correct incongruent items as compared to correct congruent items. These two findings indicated that the misinterpretation of box plots is indeed heuristic in nature.

An extra manipulation that was used by Lem et al. (2013b), related to the saliency of the box of the box plots. One group of participants solved the tasks with a large, grey box, while another group of participants solved the same tasks with a smaller, white box, in order to study the effect of saliency. The results showed that participants in the condition with the more salient area solved the tasks faster and gave more heuristic responses than the participants in the condition with the less salient area. This shows that it is indeed the area of the box plot that triggers the incorrect heuristic processing.

\section{Graph Design Principles}

Lem et al. (2013b) provided empirical evidence that the area of the box plot is interpreted incorrectly, leading to incorrect conclusions. Tversky's (1997) graph design principles provide a useful theoretical framework for understanding this misinterpretation. More specifically, the principle of the natural use of space says that space in graphs should be used in such a way as to allow for correct interpretation, much the same way space is interpreted in the real world. That means, for instance, that elements in a graph that are placed closer together should also be related more to each other than elements that are placed farther apart. Also, elements that are larger should represent more observations or should be more important. It is clear that this last rule is not obeyed to in box plots: the larger (part of the) box in the 
box plot does not represent more observations, but rather a lower density.

Another graph design principle provides a reason to assume that vertically positioned box plots may be interpreted differently than horizontally positioned ones: Tversky's (1997) directionality principle states that direction in graphs should be used in a natural way. More specifically, according to Tversky, people have a natural preference towards the vertical dimension above the horizontal dimension, meaning that they will tend to focus on the vertical dimension. This preference is likely caused by our daily experiences, for example: People and plants grow vertically, and in language concepts like 'higher' and 'larger' are associated with 'more' and 'better' (Tversky, 1997). Applying this directionality principle to box plots, it can be derived that people will tend to focus on the height of the box when positioned horizontally, because of their preference of the vertical dimension (Lem et al., 2013a, 2013b). This can lead to incorrect conclusions, since the height of the box does not reflect any meaning. When a box plot is positioned vertically, however, a focus on the vertical dimension shows the distribution of the data, which should lead to a better interpretation of the area. In other words, positioning box plots horizontally could strengthen the incorrect processing of the area, while a vertical position could lead to a focus on the vertical dimension that is more correct, hence leading to less incorrect heuristic processing.

The overall goal of the present study was to investigate whether heuristic reasoning would still occur in the interpretation of vertically positioned box plots, and if so, whether this would occur to the same extent as for horizontally positioned box plots. In accordance with Evans' (2006) dual-process theories framework, we further hypothesized that the misinterpretation of the area of the box in a vertical box plot would again be heuristic in nature.

\section{PREDICTIONS}

We already know that the graph design principle on the natural use of space causes box plots to be interpreted incorrectly. The graph design principle on the use of direction could however also play an important role in the misinterpretation of box plots, which will be tested in this study. We anticipated three possible outcomes of the current study. First, it is possible that vertically oriented box plots do not lead to incorrect heuristic reasoning, as could be predicted based on Tversky's graph design principle on the natural use of direction, meaning that it is the design principle on directionality that is most important for the interpretation of box plots. In this case, we would not find an influence of congruency on accuracy or reaction times in the vertical condition, while we would find these differences in the horizontal condition. Second, again referring to the graph design principle, one could also predict that the incorrect heuristic reasoning is less strong with vertical box plots than with horizontal ones. Both design principles play a role when this outcome is found. In this case, accuracy on the incongruent items would be higher in the vertical than in the horizontal condition, but reaction times would still reveal the occurrence of incorrect heuristic reasoning processes in the vertical condition, although to a lesser extent than in the horizontal condition. Third, incorrect heuristic reasoning may occur to the same extent in vertically and horizontally positioned box plots, as opposed to what could 
be predicted based on the graph design principle of directionality, suggesting that only the design principle on the natural use of space is determinative in the interpretation of box plots. In this case we would not find any effect of condition on accuracy or response time.

\section{METHOD}

\section{Participants}

Participants were 67 students ( 56 females, 11 males) of KU Leuven, Belgium. The strong overrepresentation of female participants was due to student enrolment patterns, but we have no reasons to assume that this gender imbalance would affect our results. The age of the participants varied between 18 and 37 years, with a mean of $22.70(\mathrm{SD}=$ 3.09). All participants had taken a statistics course in the same year or in the year before as the study was carried out and box plots were part of this course. The majority of the participants were from the Faculty of Psychology and Educational Sciences $(74.7 \%)$ The remaining participants were from various other faculties (e.g., Social Sciences, Law, and Medicine).

To test whether students in both conditions (horizontal and vertical condition) were comparable according to their box plot knowledge, a box plot knowledge test was administered after the experiment (see appendix A; Lem et al., 2013b). In general, participants correctly answered 8.82 out of the 10 $(\mathrm{SD}=1.54)$ knowledge questions about box plots, with $52.2 \%$ of the participants answering all 10 questions correctly. Based on the mean score, we can conclude that the participants' box plot knowledge was good. We did not find a statistically significant differ- ence concerning box plot knowledge, using an independent samples t-test, $\mathrm{t}(53.620)=$ $-1.947, \mathrm{p}=.057$; participants in the horizontal condition scored on average 9.18 out of 10 , while participants in the vertical condition scored on average 8.47 of 10 . This shows that both conditions were composed similarly with respect to their box plot knowledge. A calculation of the Bayes factor suggests the null hypothesis of no difference between both groups is somewhat more likely than the alternative hypothesis of a difference between both groups. The Bayes factor was 0.986 .

\section{Materials and Design}

Participants were randomly assigned to one of two conditions. In the horizontal condition ( $\mathrm{n}=33)$ participants received horizontally positioned box plots, like in the original study conducted by Lem et al. (2013b). In the vertical condition $(n=34)$ the items were identical, but the box plots were positioned vertically (see Figure 1).

All participants were presented with the same computerized test consisting of 40 items. These stimuli were created using Fathom $^{\mathrm{TM}}$ (Finzer, 2007). The computerized test was designed using E-Prime ${ }^{\circledR} 1.1$ (Psychology Software Tools, 2002). Each item consisted of two box plots, shown simultaneously on a computer screen, representing fictional exam results of two equally sized class groups. Participants had to determine in which of the two class groups there were more students with a gradehigher than 10 out of 20 . In each item there was a red dotted line to indicate the score of 10 , allowing participants to compare the box plots more easily.

As in the study of Lem et al. (2013b), five different item types were used: two congru- 

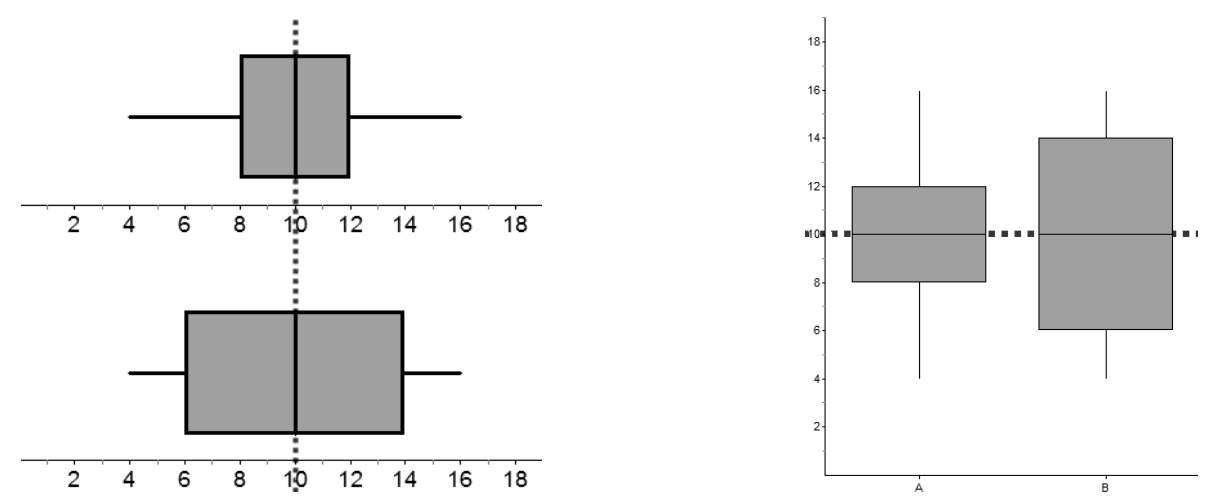

Figure 1. Example of a horizontal box plot item (left-hand figure) and its corresponding vertical box plot item (right-hand figure)

ent $(n=16)$ and three incongruent item types $(n=24)$. In the incongruent items the heuristic response was different from the correct response, whereas these two responses were the same in the congruent items. An overview of these five different item types and their correct and heuristic responses is given below and in Figure 2, giving example items from the vertical condition.

\section{Procedure}

Participants worked individually on laptop computers. The course of the experiment was the same in both conditions. No time limit was set and most participants finished the experiment within 20 minutes.

Participants were first shown a screen presenting a box plot, in which the five elements (minimum, Q1, median, Q3, maximum) were named. In the following screens they received the task instructions after which they were presented with two sample exercises for which no feedback was provided.

The 40 experimental items were presented in four units of 10 items each. Each unit was followed by a pause which participants could end themselves. In each unit the items were presented in a semi-random order, just like Lem et al. (2013b) did, in order to prevent that the same correct or heuristic response, the same level of congruency, or the same item type would be used in more than three consecutive items. Every item was preceded by a fixation cross $(+)$ in the middle of the screen, which was presented for $500 \mathrm{~ms}$. Participants did not receive any feedback about their accuracy or reaction time during the experiment.

Stickers were placed on the keyboard of the laptops in order to help the participants give their responses. In the horizontal condition, participants were asked to press " $\mathrm{T}$ " for the top box plot, "=" for equal, or "B" for bottom box plot, this way the answer buttons were positioned in the same way as the box plots were (on top of each other). In the vertical box plot condition, stickers were not placed above one another but side-by-side at one row on the keyboard: "L" for left box plot, "=" for equal, and "R" for right box plot. This way they corresponded with the verti- 


\begin{tabular}{|c|c|c|c|}
\hline & Correct response & Heuristic response & Example \\
\hline Congruent equal & $\begin{array}{l}\text { The same (the } \\
\text { same median) }\end{array}$ & $\begin{array}{l}\text { The same (same } \\
\text { area above ten) }\end{array}$ & \\
\hline Congruent unequal & $\begin{array}{l}\text { Box plot with } \\
\text { higher median }\end{array}$ & $\begin{array}{c}\text { Box plot with } \\
\text { larger area } \\
\text { above ten }\end{array}$ & \\
\hline Incongruent equal & $\begin{array}{l}\text { The same (the } \\
\text { same median) }\end{array}$ & $\begin{array}{c}\text { Box plot with } \\
\text { largest area } \\
\text { above ten }\end{array}$ & \\
\hline Incongruent unequal & $\begin{array}{l}\text { Box plot with } \\
\text { higher median }\end{array}$ & $\begin{array}{c}\text { Box plot with } \\
\text { largest area } \\
\text { above ten }\end{array}$ & \\
\hline Incongruent inverse & $\begin{array}{l}\text { Box plot with } \\
\text { higher median }\end{array}$ & $\begin{array}{c}\text { Box plot with } \\
\text { largest area } \\
\text { above ten }\end{array}$ & \\
\hline
\end{tabular}

Figure 2. Overview of the five different item types (with example items from the vertical condition). For each pair of box plots, representing the exam results of two groups of students, participants were told to choose which group had most students with a score above 10 . 
cally positioned box plots, which were placed also next to each other on the screen.

\section{RESULTS}

The reaction times of the trials were logtransformed to normalize the distribution of the data and trials with a reaction time more than 2.5 standard deviations from the mean, calculated per item type and condition, were excluded from the dataset. These trials were removed so that they could not influence the results, because such slow or fast responses could be a reflection of guessing or the loss of one's attention to a specific item. In total, this resulted in an exclusion of 20 trials $(0.8 \%)$ from the dataset.

Since there were multiple measurements per participant, the data were analyzed using generalized linear mixed models and linear mixed models, allowing to examine repeated measurements per subject and to take the possible correlation between different responses of each individual subject into consideration.

\section{Accuracy}

Table 1 provides an overview of the accuracy rates grouped per condition and level of congruency. A generalized linear mixed model was fitted to test for the main effects of condition and congruency and the interaction effect of these variables on accuracy. Accuracy was significantly higher for con- gruent $(91.0 \%)$ than for incongruent items $(64.4 \%), F(1,2591)=251.01, \mathrm{p}<.001, \mathrm{OR}=$ 8.72 , which suggests the occurrence of incorrect heuristic reasoning. Participants in the horizontal box plot condition (75.1\%) scored on average about the same as participants in the vertical box plot condition $(75.0 \%)$ and there was no statistically significant main effect of condition on accuracy, $F(1,2591)=0.62, p=.433$. Finally, there was a significant interaction effect of congruency and condition on accuracy, $\mathrm{F}(1,2591)=6.19$, $\mathrm{p}=.013, \mathrm{OR}=0.53-1.05$. As shown in Table 1 , this effect indicates that the gap in accuracy between congruent and incongruent items was somewhat larger in the horizontal than in the vertical condition.

We calculated the Bayes factor to compare the evidence for the null hypothesis that the orientation of the box plot does not have an overall effect on accuracy against the evidence for the alternative hypothesis that it does have an effect. This analysis provided strong evidence in favor of the null hypothesis, as we found a Bayes factor of 16.175 (calculated following the procedure of Rouder et al., 2009), meaning that the null hypothesis is 16.175 times more likely than the alternative hypothesis.

\section{Reaction Times}

Table 2 presents the reaction times per condition and level of congruency. A linear mixed model was used to analyze the reac-

Table 1. Accuracy rates (in \%), per condition and level of congruency

\begin{tabular}{|l|c|c|}
\hline & Horizontal condition & Vertical condition \\
\hline Congruent & 92.6 & 89.5 \\
\hline Incongruent & 63.3 & 65.4 \\
\hline
\end{tabular}


Table 2. Mean reaction times and standard deviations (in brackets) in ms of correctly solved congruent and correct incongruent items, per condition

\begin{tabular}{|l|c|c|}
\hline & Horizontal condition & Vertical condition \\
\hline Congruent & $3261(2992)$ & $3248(3285)$ \\
\hline Incongruent & $3942(3838)$ & $4555(4747)$ \\
\hline
\end{tabular}

tion times of the correct responses. Condition and level of congruency were used as independent variables in this model, as was their interaction. There was a main effect of congruency on reaction time, $\mathrm{F}(1,1929)=$ $54.65, \mathrm{p}<.001, \mathrm{~d}=0.27^{1}$. Correct responses were given faster to congruent (3254 ms) than to incongruent items (4259 ms), which again suggests the occurrence of incorrect heuristic reasoning, as more time-consuming analytic reasoning was apparently necessary to solve the incongruent items correctly. There was no main effect of condition on reaction times, $\mathrm{F}(1,1929)=0.26, \mathrm{p}=.611$, implying that participants in the horizontal and vertical box plot condition needed the same amount of time to respond correctly. Finally, there was a statistically significant interaction effect of congruency and condition on reaction time, $\mathrm{F}(1,1929)=11.54, \mathrm{p}<.001, \mathrm{~d}=0.09-0.27$. The effect of congruency on reaction time was larger in the vertical $(1307 \mathrm{~ms})$ than in the horizontal box plot condition $(681 \mathrm{~ms})$, suggesting that overcoming the incorrect heuristic is more difficult with vertically than with horizontally positioned box plots.

As we did for the accuracy rates, we also calculated the Bayes factor on the reaction times to compare the evidence for the null hypothesis, i.e., that the orientation of the

${ }^{1}$ Cohen's $d=0.20,0.50$, and 0.80 , can be considered, respectively, as indicative of a small, medium, and large effect (Cohen, Manion, Morrison, 2007). box plot does not influence the heuristic reasoning processes of the participants against the evidence for the alternative hypothesis, i.e., that it does influence the heuristic reasoning processes. We found a Bayes factor of 12.160 , suggesting that the data strongly support the null hypothesis (Rouder et al., 2009), which means that the null hypothesis is 12.160 times more likely than the alternative hypothesis.

\section{CONCLUSIONS AND DISCUSSION}

From earlier research we already know that box plots violate the graph design principle on the natural use of space (e.g., Lem et al., 2013b). In the present study we investigated the effect of a second graph design principle: the directionality principle. More specifically, we investigated whether the same reasoning processes occur when interpreting box plots that are positioned vertically as when they are positioned horizontally. Tversky's (1997) graph design principle on the use of direction provided a theoretical grounding for hypothesizing that the vertically oriented box plot might be interpreted differently than horizontally oriented box plots. As in the studies of Lem et al. (2012, 2013b), a dualprocesses approach was used to study the possible differences in reasoning processes.

The results can be summarized as follows. First, as in Lem et al.'s (2013b) study, we found for the vertical as well as the horizontal condition clear signs of incorrect heuris- 
tic reasoning, both in terms of accuracy and reaction time. Second, there was no main effect of condition, neither on accuracy nor on reaction time. On top of that, by calculating Bayes factors, we found evidence in favor of the null hypothesis that there would be no difference between both conditions regarding accuracy and reaction times. Consequently, we can conclude that the directionality principle does not have an added effect on the misinterpretation of box plots, on top of the violation of the space principle. Third, we found an interaction effect of condition and congruency on both accuracy and reaction times of correct responses. These interaction effects are difficult to interpret, especially because the direction of the effect seems to be different for accuracy and reaction time. A possible interpretation could be that the vertical presentation takes somewhat longer to process than the horizontal one, making students slightly more successful in overcoming their initial incorrect heuristic interpretation of vertical box plots. It is, however, unclear whether this is due to the longer visual processing time, making it more likely that analytic reasoning is initiated, or due to more analytic reasoning being evoked by the vertical orientation. Future research should study this further. Anyway, our results clearly indicate that the heuristic processing of the area in box plots (and thus the possible misinterpretation) also occurs in vertically oriented box plots. The violation of the design principle of the natural use of space thus affects reasoning regardless of the orientation of box plots.

The results of this study have several theoretical and practical implications. On a theoretical level, we can state that Tversky's (1997) graph design principle of directionality was not able to correctly predict that ver- tically positioned box plots would elicit different reasoning processes than horizontally positioned box plots. This might suggest that this graph design principle is incorrect. However, several other reasons could explain why we did not obtain the expected effect. For instance, even with vertically oriented box plots, some (other) problems with the design of the representation still exist, like the fact that the violation of the space principle already leads to an extremely strong misinterpretation that cannot be overcome by simply using a different orientation for the box plot. We have hence shown that people's preference of the vertical dimension over the horizontal dimension does not influence their ability of overcoming the incorrect heuristic processing of the box plot. Further research is necessary into the reasoning mechanisms concerning the interpretation of graphs and the way graph design principles can predict these mechanisms in order to find optimal designs of graphs.

On a more practical level, we have shown that for students it does not matter in which direction a box plot is presented, in terms of their likeliness to interpret the plot correctly. If these results are generalizable to other groups of users, such as policy makers and researchers reading research reports and articles, it does not matter in which direction box plots are used for the presentation of research results. Regardless, box plots should be used with care, as this study once again showed that they are not without serious interpretation difficulties.

Received October 7, 2013

\section{REFERENCES}

BAKKER, A., BIEHLER, R., KONOLD, C., 2005 , Should young students learn about box plots? 
In: G. Burill, M. Camden (Eds.), Curricular development in statistics education: International association for statistical education (IASE) 2004 roundtable (pp. 163-173). Voorburg, The Netherlands: International Statistical Institute.

COHEN, L., MANION, L., MORRISON, K., 2007, Research methods in education (6th ed.) London: Routledge.

EVANS, J.St.B.T., 2006, The heuristic-analytic theory of reasoning: Extension and evaluation. Psychonomic Bulletin \& Review, 13, 3, 378-395. doi: 10.3758/BF03193858

FINZER, W., 2007, Fathom ${ }^{T M}$ Dynamic Data Software (Version 2.1) [Computer software]. Emeryville, CA: Key Curriculum Press.

KEREN, G., SCHUL, Y., 2009, Two is not always better than one: A critical evaluation of twosystem theories. Perspectives on Psychological Science, 4, 533-550.

LEM, S., ONGHENA, P., VERSCHAFFEL, L. VAN DOOREN, W., 2012, On the misinterpretation of histograms and box plots. Educational Psychology: An International Journal of Experimental Educational Psychology, 33, 2, 155-174. doi: 10.1080/01443410.2012.674006

LEM, S., ONGHENA, P., VERSCHAFFEL, L., VAN DOOREN, W., 2013a, External representations for data distributions: In search of cognitive fit. Statistics Education Research Journal, 12, 1, 4-19.

LEM, S., ONGHENA, P., VERSCHAFFEL, L., VAN DOOREN, W., 2013b, The heuristic interpretation of box plots. Learning and Instruction, 26, 22-35. doi: 10.1016/j.learninstruc.2013.01.001

MCGILL, R., TUKEY, J.W., LARSEN W.A., 1978, Variations of box plots. The American Statistician, 32, 1, 12-16. doi: 10.1080/ 00031305.1978 .10479236

Psychology Software Tools, 2002, E-Prime ${ }^{\circledR}$ (Version 1.1) [Computer software]. New York, NY: Summit Software Company.

ROUDER, J.N., SPECKMAN, P.L., SUN, D., MOREY, R.D., IVERSON, G., 2009, Bayesian t tests for accepting and rejecting the null hypothesis. Psychonomic Bulletin \& Review, 16, 225-237. doi:10.3758/PBR.16.2.225

TVERSKY, B., 1997, Cognitive principles of graphic displays. In: Proceedings of the AAAI 1997 fall symposium on reasoning with diagrammatic representations (pp. 116-124). MIT, Menlo Park, CA: AAAI Press.

WILLIAMSON, D.F., PARKER, R.A., KENDRICK, J.S., 1989, The box plot: A simple visual method to interpret data. Annals of Internal Medicine, 110, 11, 916-921. doi: 10.7326/00034819-110-11-916

\title{
INTERPRETÁCIA RÁMČEKOVÝCH GRAFOV: VPLYV PRIESTOROVEJ ORIENTÁCIE
}

\author{
S. L e m, C. Vandebee k, P. O n g h e na, L. Verschaffel,
}

W. Va n Door e n

Súhrn: Skúmali sme ako princípy návrhu grafov predikujú špecifické mechanizmy usudzovania, ku ktorým dochádza pri skreslenej interpretácii rámčekových grafov, presnejšie, pri ich skreslenej interpretácii ako reprezentácie frekvencie alebo miery pozorovaní, a nie hustoty. Predchádzajúce štúdie ukázali, že skreslená interpretácia má heuristický charakter a vyvoláva ju skutočnost', že rámčekové grafy nevyužívajú priestor prirodzeným spôsobom. Princípy navrhovania grafov poskytujú teoretický rámec pre predpoklad, že priestorová orientácia rámčekového grafu môže ovplyvnit' jeho interpretáciu. Pomocou analýzy reakčných časov a miery presnosti pre rôzne typy položiek sme zist'ovali, či priestorová orientácia rámčekového grafu skutočne vplýva na spôsob, akým je interpretovaný. Výsledky naznačujú, že skreslená interpretácia sa vyskytovala v rovnakej miere v oboch priestorových orientáciách, na základe čoho možno predpokladat', že priestorová orientácia rámčekového grafu neovplyvňuje mechanizmy usudzovania, ktoré vyvoláva. 